\title{
Loss of the p53 tumor suppressor activity is associated with negative prognosis of mantle cell lymphoma
}

\author{
LENKA STEFANCIKOVA $^{1,2}$, MOJMIR MOULIS $^{1,3}$, PAVEL FABIAN $^{4}$, BARBORA RAVCUKOVA $^{1}$, \\ INGRID VASOVA ${ }^{5}$, JAN MUZIK ${ }^{6}$, JITKA MALCIKOVA ${ }^{5}$, IVA FALKOVA ${ }^{1}$, \\ JANA SLOVACKOVA ${ }^{1,2}$ and JANA SMARDOVA ${ }^{1,2,3}$
}

\author{
${ }^{1}$ Department of Pathology and ${ }^{5}$ Department of Hematooncology, University Hospital Brno, Jihlavska 20, 62500 Brno; \\ ${ }^{2}$ Department of Experimental Biology, Faculty of Sciences, Masaryk University, Kotlarska 2, 61137 Brno; \\ ${ }^{3}$ Faculty of Medicine and ${ }^{6}$ Institute of Biostatistics and Analyses, Masaryk University, Komenskeho namesti 2, 66243 Brno; \\ ${ }^{4}$ Department of Pathology, Masaryk Memorial Cancer Institute, Zluty kopec 7, 65653 Brno, Czech Republic
}

Received October 2, 2009; Accepted December 1, 2009

DOI: 10.3892/ijo_00000545

\begin{abstract}
Mantle cell lymphoma (MCL) is typified by translocation $\mathrm{t}(11 ; 14)(\mathrm{q} 13 ; \mathrm{q} 32)$ causing upregulation of cyclin D1 and deregulation of cell cycle. The cyclin D1 activation plays a critical role in MCL pathogenesis but additional oncogenic events, such as aberrations of the ARF/MDM2/p53 pathway are also necessary for progression of the disease. We analyzed the p53 tumor suppressor in tumor tissue of 33 patients with MCL. The p53 status was determined by functional analyses in yeast (FASAY) and by cDNA sequencing. The level of the p53 protein was assessed by immunohistochemistry and immunoblotting. Loss of the p53-specific locus $17 \mathrm{p} 13.3$ was detected by FISH. Mutations in the p53 gene were detected in nine samples and they included eight missense mutations and one short deletion causing frame shift and premature stop codon formation in position 169 . This mutation was associated with mRNA decay as revealed by sequencing of the p53 gDNA. All eight missense mutations were manifested by accumulation of the p53 protein in nuclei of tumor cells and three of them exhibited loss of the p53-specific locus 17p13.3. The p53 mutations were shown to be a negative prognostic marker in MCL.
\end{abstract}

\section{Introduction}

Mantle cell lymphoma (MCL) represents 5-10\% of nonHodgkin's lymphomas (NHLs). It is an unfavourably tumor, incurable in most patients with median survival of 3-5 years (1). MCL is typified by high expression of cyclin D1. This usually results from translocation $\mathrm{t}(11 ; 14)(\mathrm{q} 13 ; \mathrm{q} 32)$ which

Correspondence to: Dr Jana Smardova, Department of Pathology, University Hospital, Jihlavska 20, 62500 Brno, Czech Republic

E-mail: janasmarda@seznam.cz

Key words: mantle cell lymphoma, tumor suppressor p53, FASAY, overall survival, RNA decay juxtaposes the immunoglobulin heavy chain gene transcription enhancer on chromosome $14 \mathrm{q} 32$ to the proto-oncogene CCND1 (BCL1) on chromosome 11q13 encoding cyclin D1. Although the activation of cyclin D1 appears to play a critical role in pathogenesis of MCL, additional oncogenic events are necessary for progression of the disease. First, using a transgenic murine model it has been shown that cyclin D1 requires cooperation with other molecules to perform its transforming effect $(2,3)$. Second, MCL is typified by a complex karyotype with many secondary aberrations and high level of genomic instability $(4,5)$. Third, MCL represents a heterogenic group of lymphomas with different prognoses. While some patients have an extremely aggressive course of the disease, others have relatively indolent clinical course. Overall survival time ranges from only a few months to $>10$ years (1). Therefore, many attempts have been made to identify relevant prognostic markers in MCL. Recently, MIPI-prognostic index based on four clinical factors (age, Eastern Cooparative Oncology Group performance status, LDH and leukocyte count) was established (6). It allows stratification of patients into three subgroups with significantly different outcomes. Besides MIPI, several single histopathological and molecular markers have been recognized as possible prognostic factors, including tumor suppressor p53 (7). In case of MCL, the p53 status may have also predictive value. Targeting the p53 pathway has been recently recognized as a promising therapeutic approach $(8,9)$.

The p53 tumor suppressor plays an important role in cancer prevention. In response to various stress signals, p53 transactivates its target genes. Proteins encoded by these genes then control cell cycle, apoptosis, senescence, DNA repair and other cell functions, thus maintaining genome integrity (10). Somatic point mutations and allelic deletions of the p53 gene are the most frequent genetic alterations in human tumors (11). Several methods can be used to identify the p53 aberrations in clinical samples. i) Tumor cells with inactive p53 often efficiently accumulate the p53 protein due to low expression of MDM2, the negative regulator of $\mathrm{p} 53$ encoded by one of the p53-inducible genes, thus establishing 
a negative feedback loop. The p53 protein can be visualized using the p53-specific antibodies either on sections of formalin-fixed, paraffin-embedded tissue blocs by immunohistochemical analyses (IHC) or on nitrocellulose membranes after protein electrophoresis and immunoblotting (IB). ii) Molecular analyses can detect changes in a structure of genomic DNA (gDNA), mRNA, or its reverse-transcribed complementary DNA (cDNA). Direct DNA sequencing is the most reliable, though not the most sensitive method. iii) Functional assays specifically target some biological features of the p53 protein, usually its transactivation ability. Among functional tests, FASAY (functional analyses of separated alleles in yeast) has the most prominent position. It is based on evaluation of the transactivation capability of the tumorderived p53 protein that is produced from amplified tumor p53 cDNA in yeast cells (12). (iv) FISH (fluorescence in situ hybridization) is the most convenient method to demonstrate loss of the p53-specific locus 17p13.3 on chromosome 17 . Frequency and clinical outcome of the p53 aberrations have been widely studied in MCL. It has been proposed that the p53 inactivation affects $\sim 7-30 \%$ of MCL cases and it is associated with poor prognosis of the disease (13-18).

Recently, we have performed detailed analysis of cyclin D1 expression in a collection of 33 tumor samples of MCL cases (19). In this report, we present complex analysis of the p53 tumor suppressor in the same MCL collection. We determined the p53 status in each MCL sample by FASAY and analyzed the p53 mutations by cDNA sequencing. We assessed the p53 protein level both by immunohistochemical and immunoblotting analyses. We used FISH to analyze loss of heterozygosity of the p53 gene. Finally, we examined the impact of p53 alterations on prognosis of our MCL patients.

\section{Material and methods}

Samples. Thirty-three patients ( 8 females and 25 males) were included in the study. They underwent surgical removal of the tumor tissue in University Hospital in Brno from March 2003 to December 2008. For all included patients, freshfrozen tissue samples as well as formalin-fixed, paraffinembedded tumor tissue blocks were available. The average age of patients at the time of surgical intervention was 63.4 years, ranging from 39 to 80 years.

MCL diagnosis was assessed according to the criteria of the World Health Organization classification system (20). The inclusion criteria were based on typical morphology and immunophenotype $\left(\mathrm{CD} 20^{+}, \mathrm{CD}^{+}, \mathrm{CD} 10^{-}, \mathrm{CD} 23^{-}\right)$. The morphological variants were also assessed: 22 cases represented classical variant, 8 cases blastoid variant and 3 cases pleomorphic variant (20). The diagnosis was assessed by two experienced pathologists independently. Questionable/ controversial cases were solved by consensus.

Most patients (70\%) presented advanced stage disease (stages IVA and IVB). A treatment was based on the clinical behavior of the disease, 17 patients $(51 \%)$ obtained standard therapy while 16 patients $(49 \%)$ were cured by intense therapy regiments. Overall survival for the whole group was 51.7 months. According to MIPI (MCL international prognostic index) 7 patients $(21 \%)$ were classified as lowrisk (LR), 9 patients $(27 \%)$ as intermediate-risk (IMR) and
17 cases $(52 \%)$ as high-risk (HR). The clinicopathological data are summarized in Table I.

FASAY and split assay. FASAY was performed as described earlier $(12,21)$. Total RNA was purified using RNeasy mini kit (Qiagen Inc.). cDNA was synthesized by SuperScript II (Life Technologies Inc.) using oligo $(\mathrm{dT})_{12}$ as a primer. PCR was performed using primers P3 (5'-CCT-TGC-CGT-CCCAAG-CAA-TGG-ATG-AT-3'), P4 (5'-ACC-CTT-TTTGGA-CTT-CAG-GTG-GCT-GGA-GT-3'), and Pfu DNA polymerase (Stratagene). Yeast cells were co-transformed with the PCR product, linearized pSS16 plasmid, and the salmon sperm DNA carrier (Gibco BRL) by the lithium acetate procedure (22). Transformed yeast cells were plated on minimal medium lacking leucine and with a low amount of adenine $\left(5(\mu \mathrm{g} / \mathrm{ml})\right.$, followed by incubation at $35^{\circ} \mathrm{C}$ for $2-3$ days, and then for 2-3 days at room temperature. For split assay, PCR of the 5'- part of p53 was performed with primers P3 and P17 (5'-GCC-GCC-CAT-GCA-GGA-ACT-GTTACA-CAT-3), the 3'- part with primers $\mathrm{P} 4$ and $\mathrm{P} 16$ (5'-GCGATG-GTC-TGG-CCC-CTC-CTC-AGC-ATC-TTA-3'). Yeast cells were transformed with linearized vectors $\mathrm{pFW} 35$ and pFW34 (23).

Purification of the plasmids from transformed yeast cells and sequencing of the p53 cDNA. Yeast cells of individual yeast colonies were harvested, resuspended in TSN (2\% Triton $\mathrm{X}-100,1 \%$ SDS, $100 \mathrm{mM} \mathrm{NaCl}, 10 \mathrm{mM}$ Tris $\mathrm{pH}$ 8.0, $1 \mathrm{mM}$ EDTA), and grinded by vortexing with glass beads; plasmid DNA was extracted by phenol/chloroform. The p53 cDNA was amplified using P3 and P4 primers and Taq polymerase (Gibco BRL) and subjected to agarose gel electrophoresis. The PCR product was purified from a gel by MinElute PCR purification kit (Qiagen) and sequenced by BigDyeTermintor v3.1 cycle sequencing kit (Applied Biosystems) using ABI PRISM 3100 Genetic Analyzer (Applied Biosystems).

Isolation of gDNA and amplification of exon 5 of $p 53$. Genomic DNA was isolated from formalin-fixed, paraffinembedded tissue blocks using the Purogene DNA Isolation Kit (Gentra Systems, Minneapolis, MN) according to the manufacturer's instructions. Exon 5 of the p53 gene was amplified by PCR using primers p53-Pg5F (5'-CACTTGTG CCCTGACTTTCA-3'), p53-Pg5R (5'-AACCAGCCCTG TCGTCTCT-3') and Taq polymerase (Gibco BRL). The PCR product was purified and sequenced as described previously.

FISH. FISH was performed on tissue sections prepared from formalin-fixed, paraffin-embedded tissue blocks. For the p53-specific locus analysis, the Vysis LSI TP53 (17p13.1) Spectrum Orange probe and the centromeric CEP 17 Spectrum Green DNA probe were used (Abbott Molecular Inc.). Hybridization was performed according to the manufacturer's instructions. Images were scanned by Leica DMRXA2 microscope equipped with CCD camera (COHU). Fluorescence signals were analyzed using Leica Q-FISH software (Leica Microsystems GmbH, Wetzlar, Germany). Cells (50$100)$ were analyzed per case. Cells with two red and two green signals were considered negative, cells lacking one red signal were considered as containing either p53 or ATM deletion. 
Table I. Summary of clinicopathological data of analyzed samples.

\begin{tabular}{|c|c|c|c|c|c|}
\hline No. & Sex/age & Morphological variant & $\begin{array}{l}\text { MIPI } \\
\text { risk group }\end{array}$ & Treatment & $\begin{array}{c}\text { Overall survival } \\
\text { (months) }\end{array}$ \\
\hline 1 & $\mathrm{M} / 69$ & classical & HR & $\mathrm{CT}$ & 5.3 \\
\hline 2 & $\mathrm{M} / 66$ & classical & HR & IT & 32.5 \\
\hline 3 & $\mathrm{~F} / 60$ & classical & LR & IT & 66.2 \\
\hline 4 & $\mathrm{~F} / 59$ & classical & IR & $\mathrm{CT}$ & 50.0 \\
\hline 5 & $\mathrm{M} / 74$ & classical & IR & $\mathrm{CT}$ & 59.8 \\
\hline 6 & $\mathrm{M} / 55$ & classical & IR & IT & 31.4 \\
\hline 7 & $\mathrm{~F} / 65$ & pleomorphic & HR & IT & 25.4 \\
\hline 8 & $\mathrm{M} / 51$ & classical & LR & IT & 88.7 \\
\hline 9 & $\mathrm{M} / 63$ & classical & HR & IT & 0.5 \\
\hline 10 & $\mathrm{M} / 65$ & blastoid & HR & $\mathrm{CT}$ & 7.5 \\
\hline 11 & $\mathrm{M} / 79$ & classical & LR & $\mathrm{CT}$ & 48.8 \\
\hline 12 & $\mathrm{M} / 63$ & classical & HR & IT & 65.3 \\
\hline 13 & $\mathrm{M} / 71$ & classical & HR & $\mathrm{CT}$ & 54.3 \\
\hline 14 & $\mathrm{~F} / 54$ & blastoid & HR & IT & 17.7 \\
\hline 15 & $\mathrm{M} / 62$ & classical & LR & $\mathrm{CT}$ & 93.5 \\
\hline 16 & $\mathrm{M} / 74$ & blastoid & HR & $\mathrm{CT}$ & 37.8 \\
\hline 17 & $\mathrm{M} / 57$ & blastoid & IR & IT & 38.2 \\
\hline 18 & $\mathrm{M} / 54$ & classical & HR & IT & 34.0 \\
\hline 19 & $F / 39$ & pleomorphic & LR & IT & 17.4 \\
\hline 20 & $\mathrm{M} / 80$ & blastoid & HR & $\mathrm{CT}$ & 1.1 \\
\hline 21 & $\mathrm{M} / 65$ & classical & HR & $\mathrm{CT}$ & 16.0 \\
\hline 22 & M/66 & blastoid & IR & IT & 18.8 \\
\hline 23 & $\mathrm{~F} / 73$ & classical & HR & $\mathrm{CT}$ & 3.9 \\
\hline 24 & $\mathrm{M} / 53$ & classical & LR & $\mathrm{CT}$ & 84.9 \\
\hline 25 & $\mathrm{M} / 63$ & classical & IR & IT & 45.4 \\
\hline 26 & $\mathrm{~F} / 63$ & classical & HR & IT & 69.1 \\
\hline 27 & $\mathrm{M} / 68$ & classical & IR & $\mathrm{CT}$ & 16.4 \\
\hline 28 & $\mathrm{M} / 67$ & blastoid & HR & $\mathrm{CT}$ & 2.6 \\
\hline 29 & $\mathrm{M} / 73$ & blastoid & HR & $\mathrm{CT}$ & 38.5 \\
\hline 30 & $\mathrm{M} / 55$ & classical & IR & IT & 10.2 \\
\hline 31 & $\mathrm{M} / 53$ & pleomorphic & HR & IT & 9.7 \\
\hline 32 & $\mathrm{M} / 60$ & classical & LR & $\mathrm{CT}$ & 67.6 \\
\hline 33 & $\mathrm{~F} / 76$ & classical & IR & $\mathrm{CT}$ & 2.8 \\
\hline
\end{tabular}

HR, high risk; IR, intermediate risk; LR, low risk; IT, intensive treatment; CT, classical treatment.

Immunoblotting. Tissue samples were lysed in $150 \mathrm{mM} \mathrm{NaCl}$, $50 \mathrm{mM}$ NaF, $50 \mathrm{mM}$ Tris (pH 8.0), $5 \mathrm{mM}$ EDTA, $1 \%$ NP40 and $1 \mathrm{mM}$ phenylmethylsulfonyl fluoride in ice for $30 \mathrm{~min}$, and the cell extract was centrifuged at $17,000 \mathrm{x}$ g for $30 \mathrm{~min}$ to remove cell debris. Protein concentration was measured by the Bradford assay. Solubilized proteins were resolved by $10 \%$ SDS-PAGE and transferred onto a nitrocellulose membrane. Blots were blocked in $0.1 \%$ Tween-20 and 5\% low-fat milk in PBS for $1 \mathrm{~h}$ and probed with anti-p53 mouse monoclonal antibody DO-1 (kindly provided by B. Vojtesek) at $4{ }^{\circ} \mathrm{C}$. Blots were developed with Dako peroxidaseconjugated rabbit anti-mouse immunoglobulin using the ECL chemiluminescence detection kit (Amersham Biosciences, Vienna, Austria).

Immunohistochemistry. Endogenous peroxidase activity was blocked with $3 \%$ hydrogen peroxide in methanol, for $10 \mathrm{~min}$. Antigen retrieval was performed in EDTA buffer, $\mathrm{pH} 8.0$ (Dako) at $98^{\circ} \mathrm{C}$ for $25 \mathrm{~min}$. The p53-specific monoclonal antibody DO-1 (kindly provided by B. Vojtesek) was diluted 1:2000 and applied at $4^{\circ} \mathrm{C}$ overnight. Reactive sites were identified using biotinylated secondary antibody, peroxidase ABC (Vector Laboratories, Burlingame, CA, USA), DAB (Dako), and counterstained with Gill's haematoxylin. Optimal 

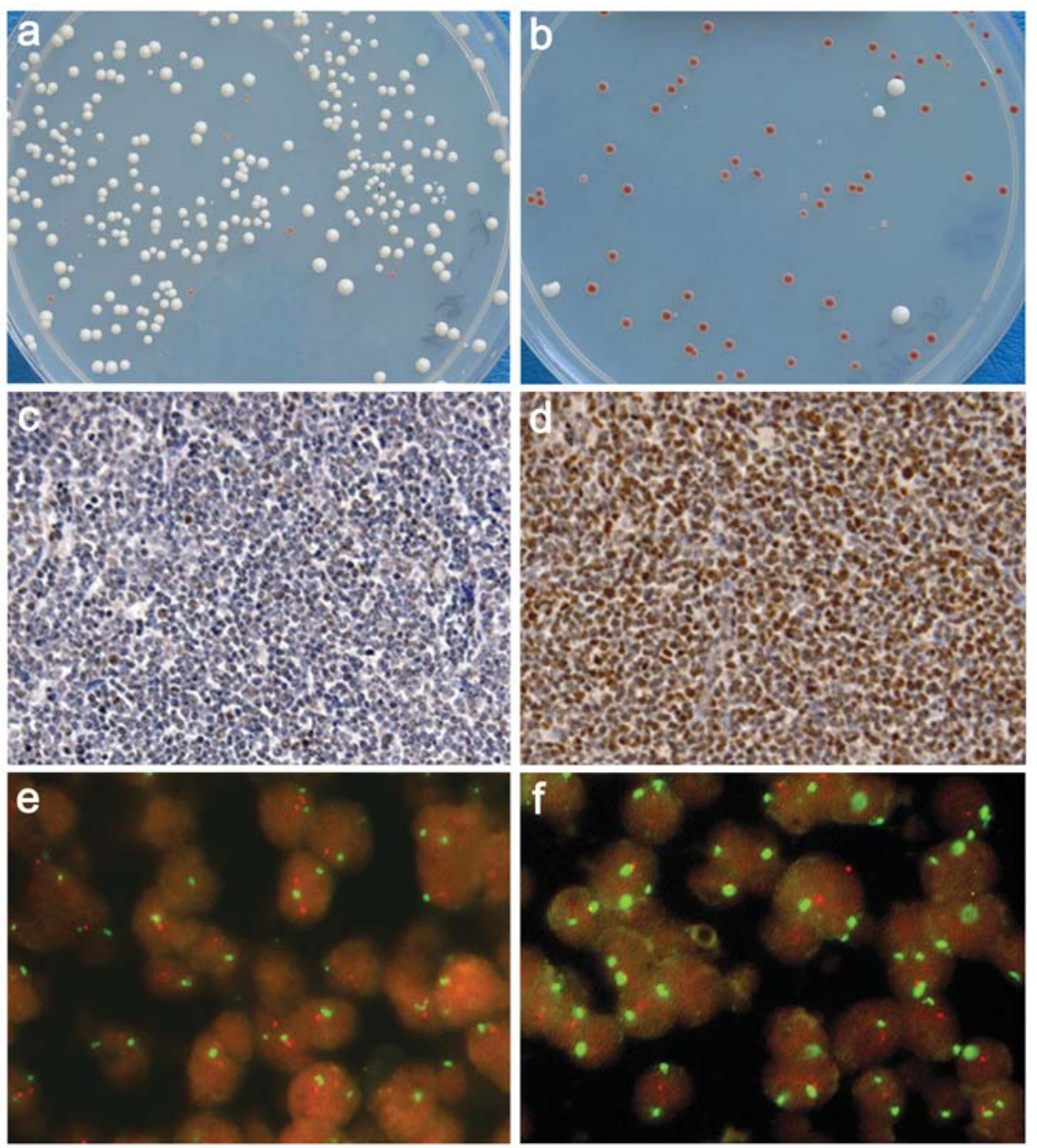

Figure 1. Analyses of the p53 status. Functional analyses of separated alleles in yeast of case 10 (a, 3.6\% of red colonies) and 20 (b, $90.6 \%$ of red colonies), immunohistochemical detection of the p53 protein using DO- 1 antibody in case $10(\mathrm{c}, 0-1)$ and $20(\mathrm{~d},+++)$, and FISH analysis of case 10 (e, $0 \%$ of positive nuclei) and 20 (f, $48 \%$ of positive nuclei).

antibody concentration was determined as the highest dilution that demonstrates positive staining in normal squamous epithelium of uterine cervix.

Statistical analyses. Kaplan-Meier OS curves stratified for assessed parameters were calculated and compared by the log-rank test. The individual risk factors constituting IPI and MIPI were checked for independent prognostic relevance by Cox proportional hazard model.

\section{Results}

Assessment of the p53 status by FASAY. FASAY deduces the functional status of p53 from color of colonies of transformed yeast cells. Yeast cells expressing functional p53 form large white colonies, while yeast cells expressing inactive p53 form smaller red colonies on indicator medium. The p53 status of analyzed sample is assessed from frequency of red colonies. The background frequency of red yeast colonies typically does not exceed $10 \%$. Thus, samples providing $<10 \%$ of red colonies are considered to contain only wild-type p53 alleles, while samples providing $>10 \%$ of red colonies are suspicious to bear a clonal p53 mutation (12). The ratio of red colonies scoring between 10 and $20 \%$ can result from a presence of clonal p53 mutation in rather small portion of cells or from increased degradation of RNA. To distinguish these two possibilities, version of FASAY, called split assay, was established. In the split assay, the 5'- and 3'-parts of the p53 cDNA are tested separately (23).

We performed FASAY of all 33 analyzed samples (Fig. 1a and b, Table II). Twenty-four cases scored under the background $10 \%$ level, eight cases were positive and scored above $20 \%$ of red colonies (ranged from 33.1 to $92.0 \%$ ). In case 31 , the result of FASAY was ambiguous as it scored $17.6 \%$. Therefore, we performed a split assay. The split assay provided asymmetric result $(12.3 \%$ of red colonies for the 3 '- part and 3.9\% for the 5'- part of the p53 cDNA) suggesting presence of a clonal p53 mutation. Overall, a clonal p53 mutation was detected in three MCL cases with classical morphological variant, and in six MCL cases with blastoid morphological variant.

Sequencing of the p53 cDNA. The cases positive in FASAY/ split assay were analyzed further by DNA sequencing. First, 
Table II. Analyses of the p53 status.

No. FASAY ${ }^{a}$ p53 mutation IB p53 IHC p53 FISH p53 ${ }^{\mathrm{b}}$

\begin{tabular}{|c|c|c|c|c|c|}
\hline 1 & 3.6 & - & - & $1+$ & 1.9 \\
\hline 2 & 6.3 & - & - & $1+$ & 0 \\
\hline 3 & 3.8 & - & - & $2+$ & 0 \\
\hline 4 & 4.1 & - & ND & $2+$ & 0 \\
\hline 5 & 8.7 & - & - & $2+$ & 0 \\
\hline 6 & 88.3 & R282W & +++ & $3+$ & 69 \\
\hline 7 & 7.1 & - & ND & $2+$ & 0 \\
\hline 8 & 4.4 & - & + & $2+$ & 0 \\
\hline 9 & 32.2 & C238S & +++ & $3+$ & 28 \\
\hline 10 & 3.6 & - & - & $0-1$ & 0 \\
\hline 11 & 3.8 & - & - & $2+$ & 0 \\
\hline 12 & 1.2 & - & - & $2+$ & 0 \\
\hline 13 & 6.8 & - & + & $2+$ & 0 \\
\hline 14 & 89.6 & R175H & +++ & $3+$ & 0 \\
\hline 15 & 4.7 & - & + & $2+$ & 0 \\
\hline 16 & 5.6 & - & - & $2+$ & 2.0 \\
\hline 17 & 82.5 & Y163C & +++ & $3+$ & 6.6 \\
\hline 18 & 4.6 & - & + & $2+$ & 0 \\
\hline 19 & 92.0 & R273H & ++ & $2+$ & 0 \\
\hline 20 & 90.6 & R248W & +++ & $3+$ & 48 \\
\hline 21 & 3.2 & - & - & $2+$ & ND \\
\hline 22 & 75.4 & C275Y & ++ & $3+$ & 0 \\
\hline 23 & 11.4 & - & - & $2+$ & 0 \\
\hline 24 & 8.2 & - & - & $3+$ & 1.5 \\
\hline 25 & 9.8 & - & - & $2+$ & 1.8 \\
\hline 26 & 6.0 & - & - & $3+$ & 0 \\
\hline 27 & 33.1 & R110L & ++ & $3+$ & 0 \\
\hline 28 & 3.6 & - & - & $3+$ & 0 \\
\hline 29 & 4.8 & - & - & $2+$ & 0 \\
\hline 30 & 8.2 & - & + & $2+$ & 0 \\
\hline 31 & 17.6 & del142C & - & $2+$ & 3.4 \\
\hline 32 & 7.5 & - & - & $2+$ & 0 \\
\hline 33 & 4.2 & - & + & $2+$ & 0 \\
\hline
\end{tabular}

aPercentage of red yeast colonies. ${ }^{b}$ Percentage of nuclei with lost of p53-specific signal. IB, immunoblotting; ND, not done.

the p53 expression vector was recovered from 3 to 6 red colonies per case. Then, the isolated DNA was used as a template for DNA sequencing. Indeed, in all nine cases, we detected clonal p53 mutation, i.e. the mutation was found in majority of analyzed colonies (Table II). Each mutation was localized to the DNA-binding domain. Eight mutations were missense. Mutation detected in case 31 was recognized as deletion of one nucleotide causing the reading frame shift and resulting in premature stop codon formation in position 169.

Detection of the 17p13.1 locus. According to the two-hit hypothesis, both alleles of the majority of tumor suppressors

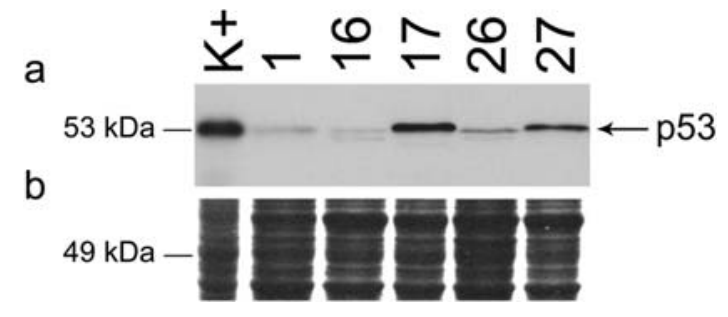

Figure 2. Assessment of the p53 protein level in tumor tissue by immunoblotting using DO-1 antibody (a); total protein fraction stained with Coomassie Brilliant Blue (b). $\mathrm{K}^{+}$, positive control-human cell line BT474bearing the E285K mutation.

undergo inactivation during cancerogenesis. The most usual way of loss of heterozygosity ( $\mathrm{LOH})$ in case of p53 is loss of the $\mathrm{p} 53$-specific locus on chromosome 17 . We analyzed the presence of this locus by FISH using the 17p13.1 locusspecific probe (Fig. 1e and f). First, we adjusted the cut-off level by the FISH analyses in tissue sections of five tumornegative lymph nodes. Frequency of the positive cells ranged from 0 to $6.6 \%$ (0-1.8-0-3.0-6.6\%). Mean plus 3-fold standard deviation $(9.6 \%)$ was considered as cut-off level. We found deletion of p53 in three cases (9.1\%). In cases 6, 9 and 20, the p53-specific locus signal was lost in 28,69 , or $48 \%$ of nuclei, respectively. The remaining p53 allele of these three samples features point missense mutations. All 30 other cases scored clearly negative (Table II).

Analysis of the p53 protein by immunoblotting and immunohistochemistry. We examined the level of the p53 protein both by immunoblotting (IB) and immunohistochemical analyses (IHC). IB was performed in 31 cases. As a positive control, we used human cell line BT474 derived from breast carcinoma, bearing mutation E285K, and accumulating high level of the p53 protein. Eight MCL samples were either strongly positive $(+++)$ on immunoblots, if they provided comparable level of the p53 protein as the positive control, or positive $(++)$, if they provided intermediate level of p53. Six samples exhibited low level of the p53 protein (+), the other samples were negative (-) (Fig. 2, Table II). All eight positive samples were shown to contain point missense p53 mutations as determined by FASAY and cDNA sequencing.

When performing IHC, we established four levels of protein: 0 , if $<5 \%$ of nuclei were stained by antibody; $1+$, if nuclear positivity varied between 5 and $35 \% ; 2+$ for positivity reaching $35-65 \%$; and $3+$ if positivity was detected in $>65 \%$ of nuclei (Fig. 1c and d). Results are summarized in Table II. We detected the highest level of p53 protein (3+) in 10 cases. Seven of them matched the positivity assessed by IB. Three IHC-positive cases $(3+)$ were negative by FASAY as well as by IB.

Analyses of the p53 status in case 31. Previous analyses documented the presence of clonal p53 mutation in case 31 . Although FASAY is rather a semi-quantitative than quantitative method, it showed clearly that the mutation is present in small fraction of analyzed cells $(17.6 \%)$. On the other hand, proportion of tumor cells in the analyzed tissue 


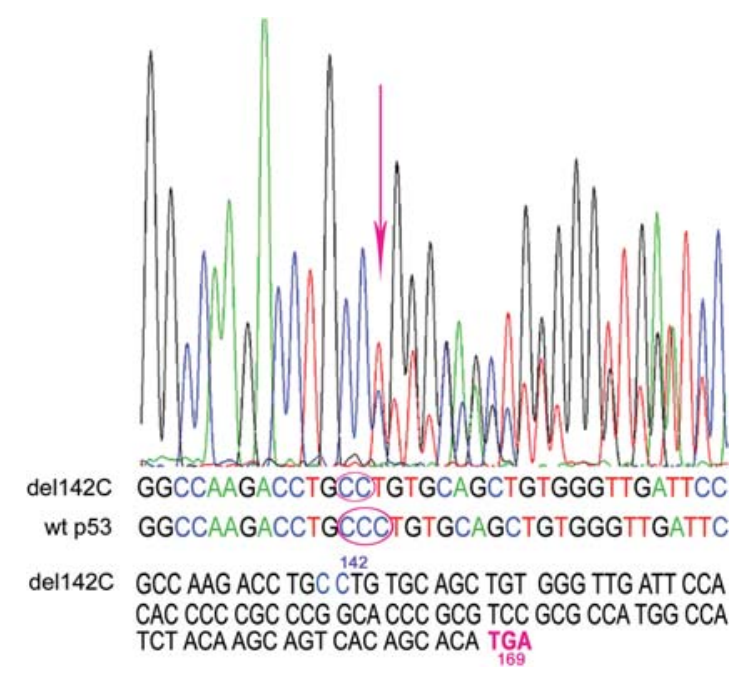

Figure 3. p53 gDNA sequencing analyses of the case 31. Arrow points the position 142 with the single cytosine deletion, which leads to formation of premature stop codon in position 169.

a

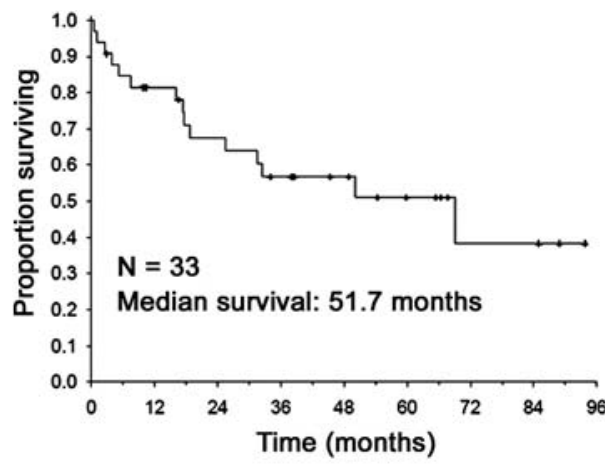

b

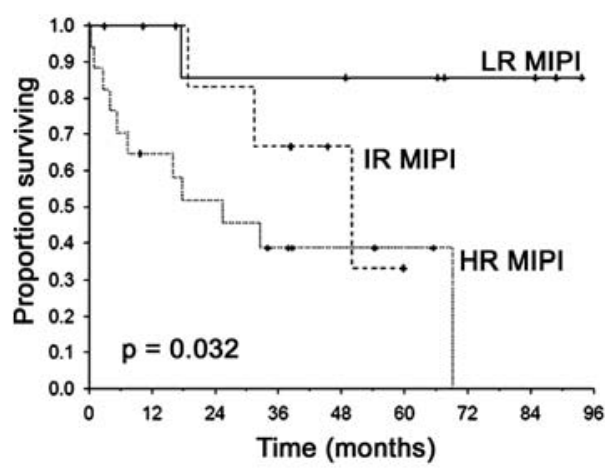

c

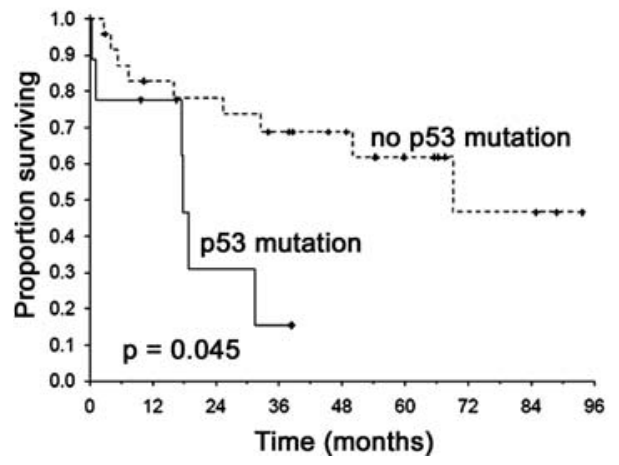

Figure 4. Overall survival curves. (a) OS of MCL patients estimated by the Kaplan-Meier survival analysis and log-rank test. (b) Difference in OS depending on MIPI risk category. (c) Difference in OS depending on the presence of the $\mathrm{p} 53$ mutation. was as high as $85 \%$. At the same time, we detected neither loss of the p53-specific locus 17 p13.3 nor accumulation of the $\mathrm{p} 53$ protein in this sample. The type of the p53 mutation we detected, e.g. deletion 142C causing frame shift and premature stop codon formation at position 169 suggests that the mutation might be associated with non-sense-mediated mRNA decay (24). To examine this possibility, we isolated gDNA from formalin-fixed, paraffin-embedded tissue block, amplified the p53 exon 5 by PCR and analyzed it by DNA sequencing (Fig. 3). The result (1) clearly confirmed the presence and the identity of the p53 mutation in this sample, and (2) showed that the mutation is present in majority of analyzed material, i.e. gDNA, while being only weakly detectable by FASAY, i.e. in RNA, thus confirming that this mutation is associated with mRNA decay.

The relationship between the p53 status and disease outcome. According to Kaplan-Meier survival curves, the median survival time of all 33 patients was 51.7 months (Fig. 4a). $67.5 \%$ of patients survived 2 years and $51.1 \%$ of patients survived 5 years. Twenty-three patients $(69.7 \%)$ reached complete remission, but almost all patients (30-90.9\%) relapsed.

To statistically evaluate the impact of the p53 aberrations and some other parameters on patient survival, KaplanMeier survival analysis and log-rank test, eventually Cox proportional hazard model were used. Neither sex, proliferation index $\mathrm{Ki}-67$, nor Bcl-2 or MDM2 protein level showed a prognostic relevance for overall survival (OS). The p53 protein level assessed by IHC also did not show statistically significant prognostic relevance. The only factors showing significant influence on patient outcome were the high-risk group as classified according to MIPI (6) (Fig. 4b) and the presence of p53 mutation in tumor cells (Fig. 4c). HR patients had median survival time of 19.8 months while IMR patients survived 41.0 months. LR patients have not reached median survival time yet ( $>96$ months; $\mathrm{p}=0.032$ ). The median survival of 9 patients with mutated p53 was 17.6 months while patients without p53 mutation survived 64.8 months $(\mathrm{p}=0.045)$. Multivariate analysis indicated that HR patients with p53 mutations have the shortest survival (median 1.1 months) while IMR and LR patients without p53 mutation lived longer (median not reached yet).

\section{Discussion}

The p53 status has been widely studied in MCL. The frequency of the p53 mutations ranged from 7 to $30 \%$ (13-18). The detection of the p53 mutations was usually based on SSCP or/and DGGE screening followed by DNA sequencing. We used for detection of the p53 mutations functional analyses in yeasts (FASAY) followed by sequencing of cDNA isolated from transformed yeast colonies (12). FASAY was previously used for analysis of two MCL-derived cell lines (25) but it has not been used for p53 analyses in MCL clinical material so far. In this study, we detected nine clonal p53 mutations in the set of $33 \mathrm{MCL}$ cases. This represents rather high frequency of the p53positive cases reaching $27.3 \%$. FASAY was repeatedly proved to be a reliable and very sensitive method and this 
fact may be at least partially responsible for higher frequency of positive cases (26). On the other hand, our set of MCL cases is rather small and the exact frequency of the p53 mutations has to be established on larger group of MCL patients.

It has been shown several times that the p53 aberrations are strongly associated with more aggressive variants of MCL $(15,16,18,27)$. Our results confirm this finding. We detected three p53 mutations among 22 classical MCL cases $(13.6 \%)$, while remaining six p53 mutations were detected among 11 more aggressive MCL variants (54.5\%). All of them were even found among eight blastoid variants (6/8-75\%). Eight of our nine p53 mutations were missense mutations $(88.9 \%)$. This result is in good agreement with the results described for MCL previously (17) and fits well to overall p53 mutation database (http://www-p53.iarc.fr;) (28).

Based on the two-hit hypothesis, loss of the second p53 allele (loss of heterozygosity-LOH) is considered as necessary event in the $\mathrm{p} 53$ inactivation during cancerogenesis (29). More or less extensive deletions of the p53 locus are considered as possible mechanism of this phenomenon. We analyzed the loss of the p53-specific locus 17p13.3 by FISH. We confirmed it only in three cases and all of them featured point missense p53 mutations. These three cases represent only $33.3 \%$ of cases bearing mutated p53 allele and only $9.1 \%$ of all analyzed MCL cases. It is a rather low frequency. Comparable low frequency (5/82-6.1\%) was observed also by other authors (17), although frequency of monoallelic deletions of the p53 locus reached $31 \%$ or even $53 \%$ in some reports $(30,31)$. The status of the second p53 allele in the six cases bearing p53 mutation but providing the two p53 signals by FISH remains questionable. It has been proposed that in some cases, mutant p53 can possess dominant-negativity when co-expressed with wild-type p53. In these cases, p53 heterotetramers containing both wild-type and mutant subunits with altered activity are formed $(32,33)$. In MCL, genome rearrangements occur frequently. Recently, a high number of uniparental disomies (UPD)/partial UPD (pUPD) was detected in MCL. UPD at $17 \mathrm{p}$ was one of the most common abberations and it was associated with p53 inactivation by point mutation (34-36). Therefore, LOH can occur without changes in DNA copy number, thus explaining the combination of negative results obtained by FISH and FASAY in which frequency of red colonies markedly exceeded $50 \%$. Another explanation of this phenomenon can be combination of mutated p53 allele with a standard allele which is silenced due to the p53 promoter mutation or methylation.

Among nine detected p53 clonal mutations, the mutation detected in case 31 was the only non-missense p53 mutation in our collection. Based on our results (low percentage of red colonies in FASAY versus high percentage of tumor cells in the analyzed tissue), we suggest that the mutation can be connected to mechanism of non-sense-mediated mRNA decay. This mechanism causes degradation of mRNA which is disqualified by prematurely included stop codon as a consequence of mutation (24). By p53 gDNA sequencing of the MCL case 31 and confronting the result with corresponding result of FASAY, we confirmed that this is indeed the case. Besides confirming an interesting example of connection of the specific p53 mutation to the RNA decay mechanism, this case also demonstrates the usefulness of the complex approaches in addressing the p53 status.

It has been proposed that the p53 inactivation is associated with poor prognosis of the disease (13-17). Although analyzing rather small group of patients, we were able clearly to confirm this finding. The difference in overall survival between MCL patients bearing p53 mutation and patients without the mutation was substantial; 17.6 months versus 64.8 months $(\mathrm{p}=0.045)$. In summary, we clearly showed that 1) the frequency of the p53 mutation in MCL tumors is reasonably high; 2) the p53 mutations are strongly associated with the more aggressive morphologic variants of the disease; and 3) the p53 mutation is an independent negative prognostic marker for MCL.

\section{Acknowledgements}

This work was supported by grant NR/9305-3 of the Internal Grant Agency of the Ministry of Health of the Czech Republic, MSM0021622415 of the Ministry of Education, Youth and Sports of the Czech Republic, and 204/08/H054 of Grant Agency of Czech Republic.

\section{References}

1. Herrmann A, Hoster E, Zwingers T, Brittinger G, Engelhard M, Meusers P, Reiser M, Forstpointerner R, Metzner B, Peter N, Wormann B, Trumper L, Pfreundschuh M, Einsele H, Hiddemann W, Unterhalt $\mathrm{M}$ and Dreyling M: Improvement of overall survival in advanced stage mantle cell lymphoma. J Clin Oncol 27: 511-518, 2009.

2. Bodrug SE, Warner BJ, Bath ML, Lindeman GJ, Harris AW and Adams JM: Cyclin D1 transgene impedes lymphocyte maturation and collaborates in lymphomagenesis with the myc gene. EMBO J 13: 2124-2130, 1994.

3. Lovec H, Grzeschiczek A, Kowalski MB and Moroy T: Cyclin D1/bcl-1 cooperates with myc genes in the generation of B-cell lymphoma in transgenic mice. EMBO J 13: 3487-3495, 1994

4. Salaverria I, Perez-Galan P, Colomer D and Campo E: Mantle cell lymphoma: from pathology and molecular pathogenesis to new therapeutic perspectives. Haematologica 91: 11-16, 2006.

5. Ferreira BI, Garcia JF, Suela J, Mollejo M, Camacho FI, Carro A, Montes S, Piris MA and Cigudosa JC: Comparative genome profiling across subtypes of low-grade B-cell lymphoma identifies type-specific and common aberrations that target genes with a role in B-cell neoplasia. Haematologica 93: 670-679, 2008.

6. Hoster E, Dreyling M, Klapper W, Gisselbrecht C, van Hoof A, Kluin-Nelemans HC, Pfreundschuh M, Reiser M, Metzner B, Einsele H, Petr N, Jung W, Wormann B, Ludwig WD, Duhrsen U, Eimermacher H, Wandt H, Hasford J, Hiddemann W and Unterhalt M: A new prognostic index (MIPI) for patients with advanced-stage mantle cell lymphoma. Blood 111: 558-565, 2008.

7. Hartmann EM, Ott G and Rosenwald A: Molecular outcome prediction in mantle cell lymphoma. Future Oncol 5: 63-73, 2009.

8. Jones RJ, Chen Q, Voorhees PM, Young KH, Bruey-Sedano N, Yang D and Orlowski RZ: Inhibition of the p53 E3 ligase HDM-2 induces apoptosis and DNA damage-independent p53 phosphorylation in matle cell lymphoma. Clin Cancer Res 14: 5416-5425, 2008.

9. Tabe Y, Sebasigari D, Jin L, Rudelius M, Davies-Hill T, Mikyake K, Miida T, Pittaluga S and Raffeld M: MDM2 antagonist Nutlin-3 displays antiproliferative and proapoptotic activity in mantle cell lymphoma. Clin Cancer Res 15: 933-942, 2009.

10. Vousden KH: Outcomes of p53 activation-spoilt for choice. J Cell Sci 119: 5015-5020, 2006.

11. Hainaut P and Hollstein M: p53 and human cancer: the first ten thousand mutations. Adv Cancer Res 77: 81-137, 2000. 
12. Flaman JM, Frebourg T, Moreau V, Charbonnier F, Martin C, Chappuis P, Sappino AP, Limacher JM, Bron L, Benhattar J, Tada M, Van Meir EG, Estreicher A and Iggo RD: A simple p53 functional assay for screening cell lines, blood, and tumors. Proc Natl Acad Sci USA 92: 3963-3967, 1995.

13. Zoldan MC, Inghirami G, Masuda Y, Vandekerchhove F, Raphael B, Amorosi E, Hymes K and Frizzera G: Large-cell variants of mantle cell lymphoma: cytologic characteristics and p53 anomalies may predict poor outcome. Br J Haematol 93: 475-486, 1996.

14. Koduru PR, Raju K, Vadmal V, Menezes G, Shah S, Susin M, Kolitz J and Broome JD: Correlation between mutation in p53, p53 expression, cytogenetics, histologic type, and survival in patients with B-cell non-Hodgkin's lymphoma. Blood 90: 4078-4091, 1997.

15. Greiner TC, Moynihan MJ, Chan WC, Lytle DM, Pedersen A, Anderson JR and Weisenburger DD: p53 mutations in mantle cell lymphoma are associated with variant cytology and predict a poor prognosis. Blood 87: 4302-4310, 1996.

16. Hernandez L, Fest T, Cazorla M, Teruya-Feldestein J, Bosch F, Peinado MA, Piris MA, Montserrat E, Cardesa A, Jaffe ES, Campo E and Raffeld M: p53 gene mutation and protein overexprssion are associated with aggressive variants of mantle cell lymphomas. Blood 87: 3351-3359, 1996.

17. Greiner TC, Dasgupta C, Ho VV, Weisenburger DD, Smith LM Lynch JC, Vose JM, Fu K, Armitage JO, Braziel RM, Campo E, Delabie J, Gascoyne RD, Jaffe ES, Muller-Hermelink HK, Ott G, Rosenwald A, Staudt LM, Im MY, Karaman MW, Pike BL, Chan WC and Hacia JG: Mutation and genomic deletion status of ataxia telangiectasia mutated (ATM) and p53 confer specific gene expression profiles in mantle cell lymphoma. Proc Natl Acad Sci USA 103: 2352-2357, 2006.

18. Hernandez L, Bea S, Pinyol M, Ott G, Katzenberger T, Rosenwald A, Bosch F, Lopez-Guillermo A, Dealbie J, Colomer D, Monserrat E and Campo E: CDK4 and MDM2 gene alterations mainly occur in highly proliferative and aggressive mantle cell lymphomas wild-type INK4a/ARF locus. Cancer Res 65: 2199-2206, 2005.

19. Stefancikova L, Moulis M, Fabian P, Falkova I, Vasova I, Kren L, Macak J and Smardova J: Complex analysis of cyclin D1 expression in mantle cell lymphoma: Two cyclin D1-negative cases detected. J Clin Pathol 69: 948-950, 2009.

20. Swerdlow SH, Campo E, Seto M and Muller-Hermelink: Mantle cell lymphoma. In: WHO Classification of Tumours of Haematopoietic and Lymphoid Tissues. Swerdlow SH, Campo E, Harris NL, Jaffe ES, Pileri SA, Stein H, Thiele J and Vardiman JW (eds). IARC Press, Lyon, pp229-232, 2008.

21. Smardova J, Nemajerova A, Trbusek M, Vagunda V and Kovarik J: Rare somatic p53 mutation identified in breast cancer: a case report. Tumor Biol 22: 59-66, 2001.

22. Ishioka C, Frebourg T, Yan YX, Vidal M, Friend SH, Schmidt S and Iggo R: Screening patients for heterozygous p53 mutations using a functional assay in yeast. Nat Genet 5: 124-129, 1993.

23. Waridel F. Estreicher A, Bron L, Flaman JM, Fontolliet C, Monnier P, Frebourg T and Iggo R: Field cancerisation and polyclonal p53 mutation in the upper aerodigestive tract. Oncogene 14: 163-169, 1997.
24. Silva AL and Romao L: The mammalian nonsense-mediated mRNA decay pathway: To decay or not to decay! Which players make the decision? FEBS Lett 583: 499-505, 2009.

25. M'kacher R, Bennaceur A, Farace F, Lauge A, Plassa LF, Wittmer E, Dossou J, Violot D, Deutsch E, Bourhis J, StoppaLyonnet D, Ribrag V, Carde P, Parmentier C, Bernheim A and Turhan AG: Multiple molecular mechanisms contribute to radiation sensitivity in matle cell lymphoma. Oncogene 22: 7905-7912, 2003.

26. Meinhold-Heerlein I, Ninci E, Ikenberg H, Brandstetter T, Ihling C, Schwenk I, Straub A, Schmitt B, Bettendorf H, Iggo R and Bauknecht T: Evaluation of methods to detect p53 mutations in ovarian cancer. Oncology 60: 176-188, 2001.

27. D'Khoury J, Medeiros LJ, Rassidakis GZ, McDonnell TJ, Abruzzo LV and Lai R: Expression of Mcl-1 in mantle cell lymphoma is associated with high-grade morphology, a high proliferative state, and p53 overexpression. J Pathol 199: 90-97, 2003.

28. Olivier M, Eeles R, Hollstein M, Khan MA, Harris CC and Hainaut P: The IARC TP53 database: new online mutation analysis and recommendations to users. Hum Mutat 19: 607-614, 2002.

29. Knudson AG Jr: Mutation and cancer: statistical study of retinoblastoma. Proc Natl Acad Sci USA 68: 820-823, 1971.

30. Stocklein H, Hutter G, Kalla J, Hartmann E, Zimmermann Y, Katzenberger T, Adam P, Leich E, Holler S, Muller-Hermelink HK, Rosenwald A, Ott G and Dreyling M: Genomic deletion and promoter methylation status of hypermethylated in cancer 1 (HIC1) in matle cell lymphoma. J Hematopathol 1: 85-95, 2008.

31. Solenthaler M, Matutes E, Brito-Babapulle V, Morilla R and Catovsky D: p53 and mdm2 in mantle cell lymphoma in leukemic phase. Haematologica 87: 1141-1150, 2002.

32. Milner J and Medcalf EA: Cotranslation of activated mutant p53 with wild-type drives the wild-type p53 protein into the mutant conformation. Cell 65: 765-774, 1991.

33. Soussi T and Beroud C: Assessing TP53 status in human tumours to evaluate clinical outcome. Nat Rev 1: 233-240, 2001.

34. Bea S, Salaverria I, Armengol L, Pinyol M, Fernadez V, Harmann EM, Jares P, Amador V, Hernandez L, Navarro A, Ott G, Rosenwald A, Estivill X and Campo E: Uniparental disomies, homozygous deletions, amplifications, and target genes in mantle cell lymphoma revealed by integrative high-resolution whole-genome profiling. Blood 113: 3059-3069, 2009.

35. Vater I, Wagner F, Kreuz M, Berger H, Martin-Subero JI, Pott C, Martinez-Climent JA, Klapper W, Krause K, Dyer MJS, Gesk S, Harder L, Zamo A, Dreyling M, Hasenclever D, Arnold N and Siebert R: GeneChip analyses point to novel pathogenetic mechanisms in mantle cell lymphoma. Br J Haematol 144: 317-331, 2009.

36. Kawamata N, Ogawa S, Gueller S, Ross SH, Huynh T, Chen J, Chang A, Nabavi-Nouis S, Megrabian N, Siebert R, MartinezCliment JA and Koeffler HP: Identified hidden genomic changes in mantle cell lymphoma using high-resolution single nucleotide polymorphism genomic array. Exp Hematol 37: 937-946, 2009. 